\begin{tabular}{lccc} 
& GOSPODARKA & SUROWCAMI & MINERALNYMI \\
\hline Tom 29 & 2013 & Zeszyt 4 \\
& & DOI 10.2478/gospo-2013-0043 &
\end{tabular}

\title{
Natural Gas Economy in the United States and European Markets
}

\section{Introduction}

In 2012 the world's natural gas consumption increased by approximately $2 \%$ compared to the previous year, reaching 3.3 trillion cubic metres $(\mathrm{tcm})$. The dynamics of the changes in the consumption structure varied. While in the case of North America significant growth in consumption was observed, totalling $27.5 \%$, EU countries recorded a decrease of $2.3 \%$ in natural gas consumption. Examining this variability in selected countries, both in the American and European markets, even greater disparities can be seen. The United States saw an increase of $21.9 \%$, the United Kingdom a drop of 5.7\%, Portugal a decrease of 9.8\%. Considering the changes in natural gas demand in these two major markets over a longer term, specifically the years 2003 to 2011, the following conclusions can be drawn: the American market recorded an increase of $16.2 \%$ in gas demand, while at the same time the European market recorded a $6.3 \%$ decline. Taking a closer look at these markets from 2003-2008, they both demonstrated a growing demand for natural gas of approximately $5 \%$ (in the European Union, the year 2008 saw a record-breaking level of gas consumption 497.3 billion cubic metres (bcm) (BP 2013). In the following years, though, they behaved differently. In an attempt to understand the factors which significantly affect the natural gas economy in the US and European markets, the effects of the so-called shale gas revolution in North America are primary considerations. The growth in unconventional gas supplies has had an effect on gas prices. While a few years ago gas prices were at a similar level in the analysed markets, at its lowest levels in 2012 the US's natural gas cost one-fifth the import

* Ph.D. Eng., ** M.Sc. Eng., AGH University of Science and Technology, Kraków, Poland; e-mail: szua@agh.edu.pl 
prices in Europe, and one-eighth those on the Japanese market (IEA 2012). Certainly, the occurrence of the financial crisis five years ago, with a symbolic date of September 15, 2008 and the collapse of Lehman Brothers, followed by the economic crisis affecting many countries, including within the European Union, are factors that have affected the demand for energy carriers like natural gas as well. Given the important character of natural gas in electricity generation, a broader perspective is needed in order to analyse the changes in the natural gas economy in the American and European markets. This includes evaluating the international steam coal trade, the electricity and power generation sector, and, in particular, the expanded use of renewable energy resources (RES). The growing role of RES in the energy mix of EU countries, as well as the increasing role of coal, has weakened natural gas's position in the European energy market.

\section{Natural gas trade}

An important feature of proven natural gas resources is that they are unevenly distributed; over $60 \%$ of global resources are found only in five countries, namely the Russian Federation, Iran, Turkmenistan, Saudi Arabia, and the United States. In 2012 these countries' share in global gas extraction reached $47.6 \%$. International trade in this energy carrier is growing (Fig. 1). The amount of $705.5 \mathrm{bcm}$ of natural gas was transmitted through gas pipelines in 2012 (approx. 1\% more compared to 2011), and the transport of liquefied gas was at $327.9 \mathrm{bcm}$ (approx. $0.5 \%$ less compared to the previous year). These figures relate to natural gas being traded between countries. In the years 2001-2012, the international natural gas trade increased by $86.4 \%$. A gradually increasing importance of LNG technologies is visible. For example, in 2005 the share of LNG in total trade accounted for 26\%, and in 2012 for $32 \%$ (BP 2002-2013). Further growth in the LNG trade is to be expected, given US liquefied gas export plans (Kaliski et al. 2013).

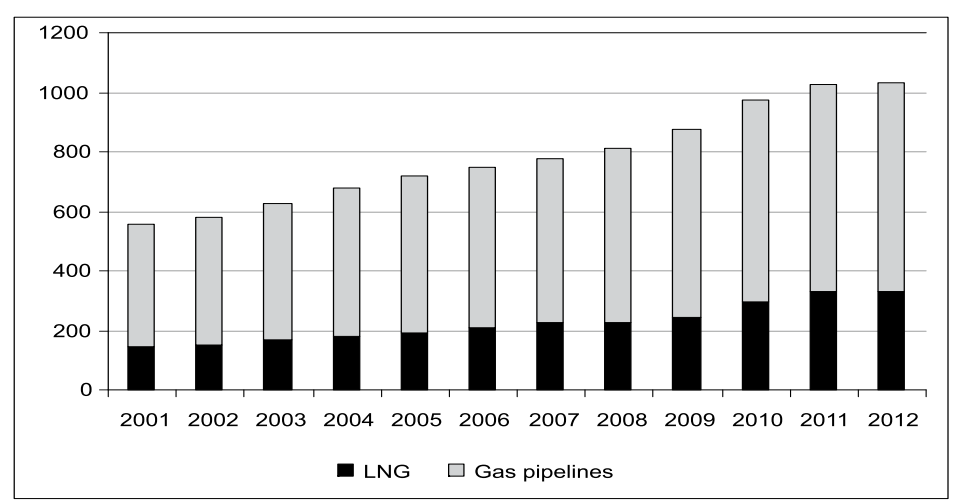

Fig. 1. Share of LNG in global natural gas trade [bcm] Source: the authors' own work based on BP 2002-2013

Rys. 1. Udział skroplonego gazu ziemnego w światowym handlu gazem [mld $\left.\mathrm{m}^{3}\right]$ 
Natural gas's position is visibly strengthening in the case of the US market $(28.3 \%$ in $2011 ; 30.0 \%$ in 2012), and declining slightly in Europe (24.2\% in $2011 ; 23.9 \%$ in 2012 ) (BP 2013). There has been a decline in import dependency in the case of North America (mainly owing to the increased volume of unconventional gas), while a growing European dependency on natural gas imports can be observed (Table 1). As regards European countries, Denmark and the Netherlands (not included in Table 1) are currently the only net exporters of natural gas. In the majority of countries, imports the role of which is growing are vital to balance the demands for natural gas (in most EU countries the level of gas imports exceeds 90\%). This is particularly noticeable in the example of the United Kingdom, which as recently as at the beginning of the $21^{\text {st }}$ century has balanced the demands for natural gas by its own extraction from offshore reserves. However, with those reserves being gradually depleted, production has declined steadily and imports have become necessary. In 2012 the United Kingdom ranked third in the EU, with imports amounting to $35.4 \mathrm{bcm}$. Poland's dependence on gas imports amounts to approximately $70 \%$, which is to be interpreted positively given the increasing consumption of gas in the country in recent years. In Canada throughout the period considered, not only did the amount of gas extracted entirely meet the domestic needs of the country, but excess gas was also exported to the United States.

North American countries also hold a clear advantage over EU countries with respect to energy security when considering the broader range of energy raw materials (Fig. 2).

TABLE 1

Natural gas import dependency in selected countries from 1990-2012 [\%]

TABELA 1

Poziom uzależnienia od importu gazu ziemnego w wybranych państwach w latach 1990-2012 [\%]

\begin{tabular}{|c|c|c|c|c|c|c|c|c|c|}
\hline Country & 1990 & 1995 & 2000 & 2005 & 2008 & 2009 & 2010 & 2011 & 2012 \\
\hline Austria & 85.7 & 84.9 & 80.3 & 88.1 & 87.1 & 85.2 & 74.4 & 103.3 & 86.3 \\
\hline Denmark & -51.1 & -47.3 & -64.7 & -113.9 & -120.8 & -91.8 & -68.3 & -67.1 & -70.3 \\
\hline Hungary & 58.0 & 60.3 & 75.5 & 81.1 & 88.4 & 85.6 & 78.7 & 65.6 & 72.2 \\
\hline Poland & 75.8 & 64.5 & 66.4 & 69.7 & 72.7 & 67.7 & 69.3 & 75.1 & 73.8 \\
\hline Spain & 74.2 & 97.4 & 101.6 & 101.3 & 100.9 & 98.9 & 99.3 & 101.6 & 99.4 \\
\hline France & 93.6 & 92.9 & 100.0 & 99.3 & 97.8 & 100.9 & 92.9 & 103.5 & 96.8 \\
\hline Italy & 64.9 & 63.9 & 81.1 & 84.8 & 90.3 & 88.6 & 90.5 & 90.2 & 90.2 \\
\hline Germany & 75.9 & 78.6 & 79.1 & 81.3 & 84.5 & 87.9 & 81.9 & 88.5 & 86.0 \\
\hline United Kingdom & 13.1 & 1.0 & -10.6 & 6.7 & 26.1 & 31.6 & 37.7 & 44.2 & 47.1 \\
\hline Canada & -59.4 & -79.6 & -109.6 & -98.7 & -93.3 & -78.6 & -76.7 & -60.9 & -56.6 \\
\hline United States & 7.0 & 8.6 & 15.0 & 16.6 & 12.8 & 11.7 & 10.9 & 8.1 & 6.0 \\
\hline
\end{tabular}

Source: the authors' own work based on (IEA 2000-2013a) 
The dependency level on all energy materials in selected countries indicates Canada as a leader not only in energy self-sufficiency, but also as a significant exporter of raw materials for energy generation. This is on the one hand because of Canada's significant hydrocarbon deposits and the significant role of hydroelectricity in power generation, and on the other because of low population density for such a geographically vast country. The example of the US shows a gradual decline in dependency on imported energy materials in recent years, which is to be associated mainly with the successful development of unconventional hydrocarbon reserves (Michałowski et al. 2012). Poland's dependency on imported energy resources compares favourably with other EU countries. For 2012, this amounted to $31.2 \%$ two times lower than in Germany (Janusz 2010).

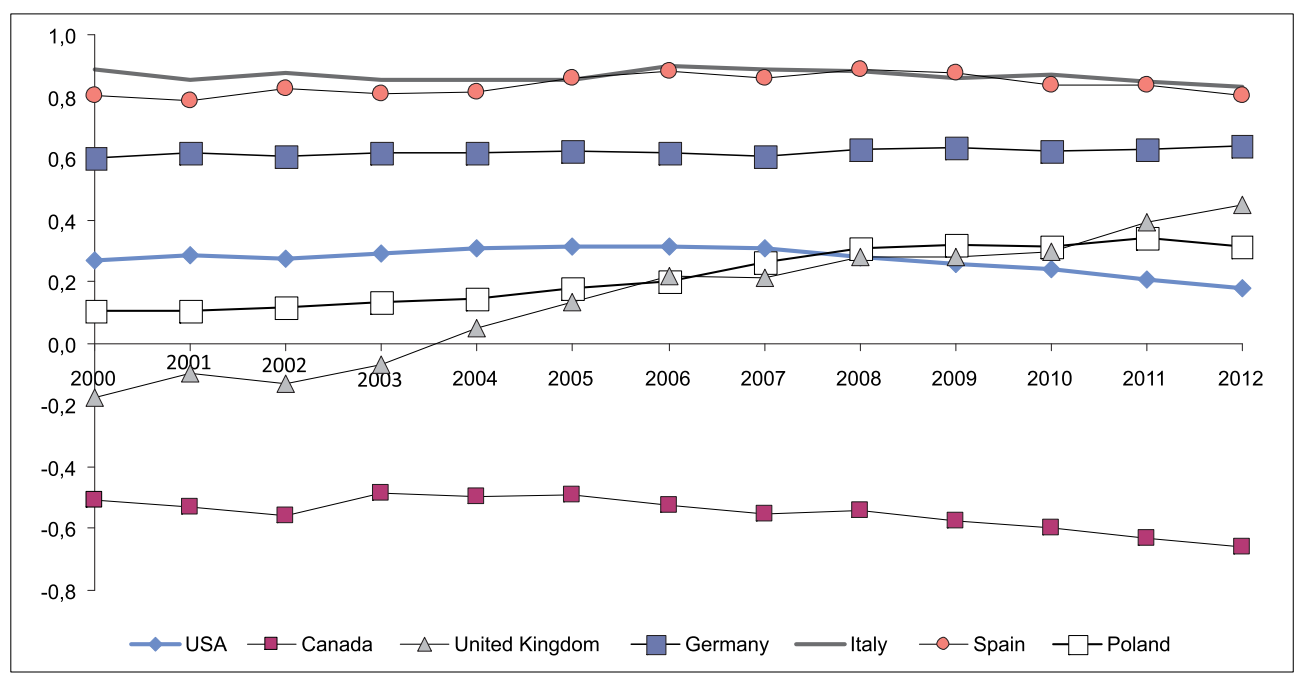

Fig. 2. Dependency on imported raw materials for energy generation from 2000-2012 Source: the authors' own work based on (IEA 2000-2013a)

Rys. 2. Uzależnienie od importu surowców energetycznych w latach 2000-2012

\section{Natural Gas Demand - Outlook}

According to the forecast of the International Energy Agency (IEA) presented in the World Energy Outlook 2012, global demand for energy will increase over the period to 2035, depending on the scenario, by $20 \%$ to $50 \%$ as compared to the consumption in 2010 . China, India, and the Middle East will account for some $60 \%$ of this increase. The demand for energy is growing slightly in OECD countries, but at the same time a pronounced shift is being observed away from oil and coal (and, in some countries, nuclear power) towards natural gas and renewables (RES). Despite the increased share of low-carbon sources of energy, fossil fuels remain dominant in the global energy mix (IEA 2012). 
The current developments in the energy market mean that no country is an energy island, and the interactions between various energy carriers and their prices are intensifying. The best example of the existing interactions is the current situation in the United States where low gas prices translate into reduced coal use. Price relationships between regional natural gas markets will strengthen as LNG trade becomes more flexible and contract terms evolve, which means that changes in one part of the world are felt more quickly elsewhere. Natural gas is the only fossil fuel for which the demand grows in all scenarios (Fig. 3), but the outlook is different in various regions. Strong growth in demand is projected in China, India, and in the Middle East. Active policy support and regulatory reforms will push China's gas consumption up from around $130 \mathrm{bcm}$ in 2011 to $545 \mathrm{bcm}$ in 2035. In the United States, low prices and an abundant natural gas supply will cause this commodity to overtake oil around 2030. Unconventional gas will account for nearly half of the increase in global gas production to 2035. Most of the increase will come from China, the United States, and Australia. But the unconventional gas business is still in its formative years, with uncertainty in many countries about the extent and quality of the resources. There are also concerns about the environmental impacts of unconventional gas exploration and extraction.

Taking account of the aforementioned projections for natural gas, the International Energy Agency projected that in 2035 important changes will take place in terms of selected countries/regions' dependency on hydrocarbon imports. For the majority of countries, an increased gas import dependency is projected - for the European Union this growth is estimated at over $80 \%$ by 2035 . However, the United States is projected to shift from an importer of hydrocarbons to an exporter (Siemek, Nagy 2012) - Fig. 4.

Projections for future natural gas demand are related to projections for future natural gas prices, as shown in Figure 5. This figure shows projections (IEA 2012) for natural gas

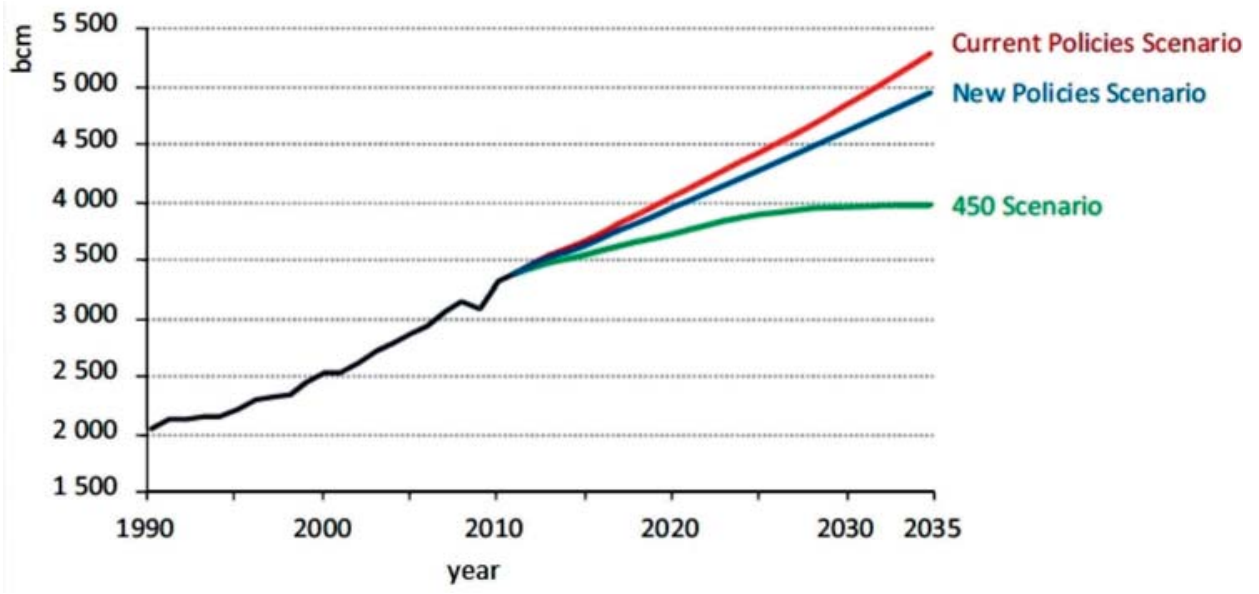

Fig. 3. Global gas demand depending on the scenario Source: IEA 2012

Rys. 3. Światowe zapotrzebowania na gaz ziemny w zależności od scenariusza 


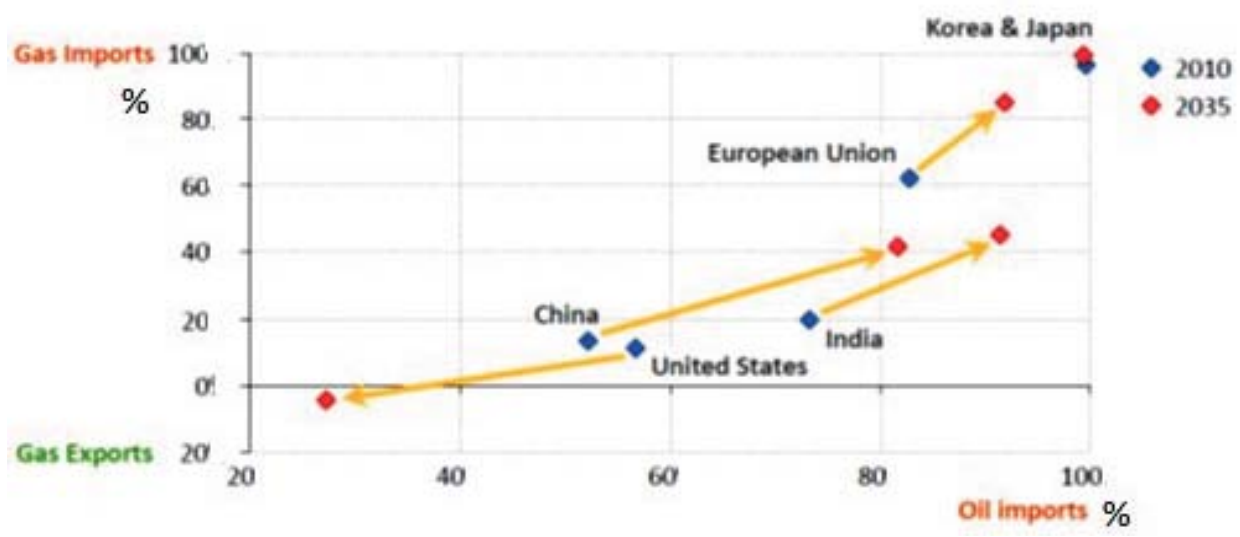

Fig. 4. Outlook of net oil \& gas import dependency in selected countries Source: Van der Hoeven 2012

Rys. 4. Prognoza zmiany uzależniania od importu węglowodorów w wybranych krajach

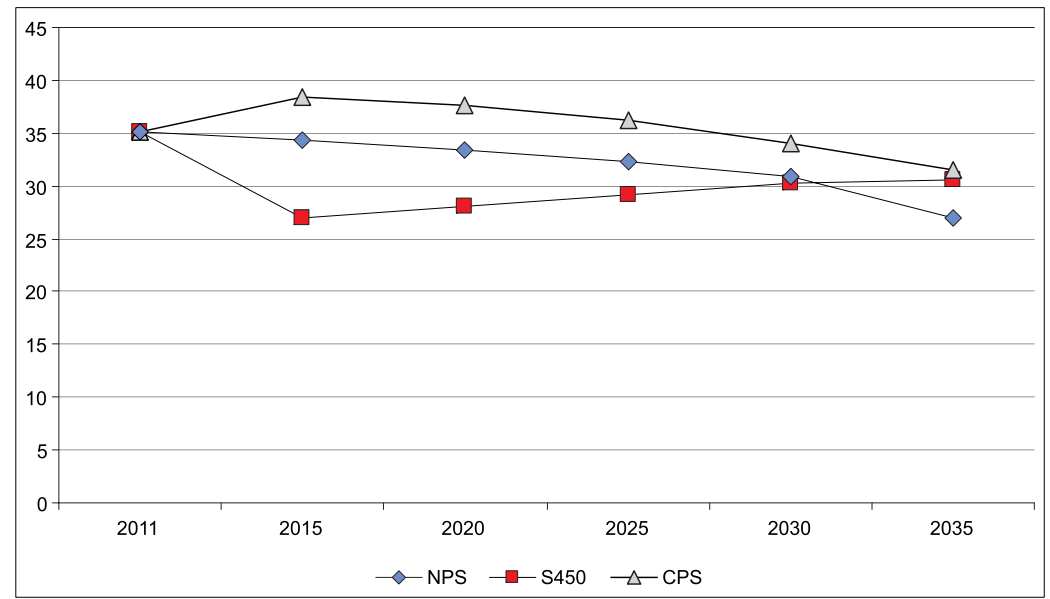

Fig. 5. Natural gas import prices into Europe depending on the scenario to 2035 Source: the authors' own work based on IEA 2012

Rys. 5. Ceny importu gazu ziemnego do Europy w zależności od scenariusza w perspektywie do $2035 \mathrm{r}$.

import prices into Europe by 2035 in all scenarios the NPS (New Policies Scenario), the central scenario of the WEO 2012; the S450 (450 Scenario); and the CPS (Current Policies Scenario). Each of these scenarios projects a downward trend. When comparing the outlook (IEA 2012) with the preceding version (IEA 2009), it is evident that for the reference scenario the projected gas prices are reduced by $13 \%$ in 2025 and by $27 \%$ in 2030 respectively. The decrease in future gas prices is undoubtedly to be associated with successful unconventional gas development and its impact on global natural gas supplies. 


\section{Price trends}

Figure 6 shows the fluctuations in natural gas prices in the American and European (as well as Japanese) markets compared to the trends for crude oil prices (Brent) and coal (CIF ARA). As noted, in the years 2000-2006 gas prices in the American, Japanese, and European markets were on the increase and following roughly the same pattern, and between 2003 and 2005 the highest gas prices were noticed in the American market. The crisis of 2008 resulted in dramatic price reductions in energy markets with the largest price decrease in the US gas market, by $56 \%$ between 2008-2009. During this period, mainly due to the crisis, the demand for natural gas decreased (by $10 \mathrm{bcm}$ ), and the production of unconventional gas increased (by $13 \mathrm{bcm}$ ). Since 2009, the prices of natural gas (European and Japanese market) as well as crude oil and coal have been steadily growing, the last having decreased since 2011. Prices in the US gas market continued to decline - between 2011 and 2012 the gas prices per unit of energy moved lower than the CIF ARA coal prices, with the continued production of unconventional gas translating into lower gas prices in the United States. This corresponded with an over two-and-a-half-fold rise in shale gas production between 2009-2011. In 2011 shale gas had a 34\% share in the total production, and in 2012 the share increased to $39 \%$. The substantial increase in gas prices in Japan in 2011, in contrast, should be explained primarily by the consequences of the Fukushima nuclear disaster (prior to the disaster, nuclear energy had provided a quarter of the country's electricity production).

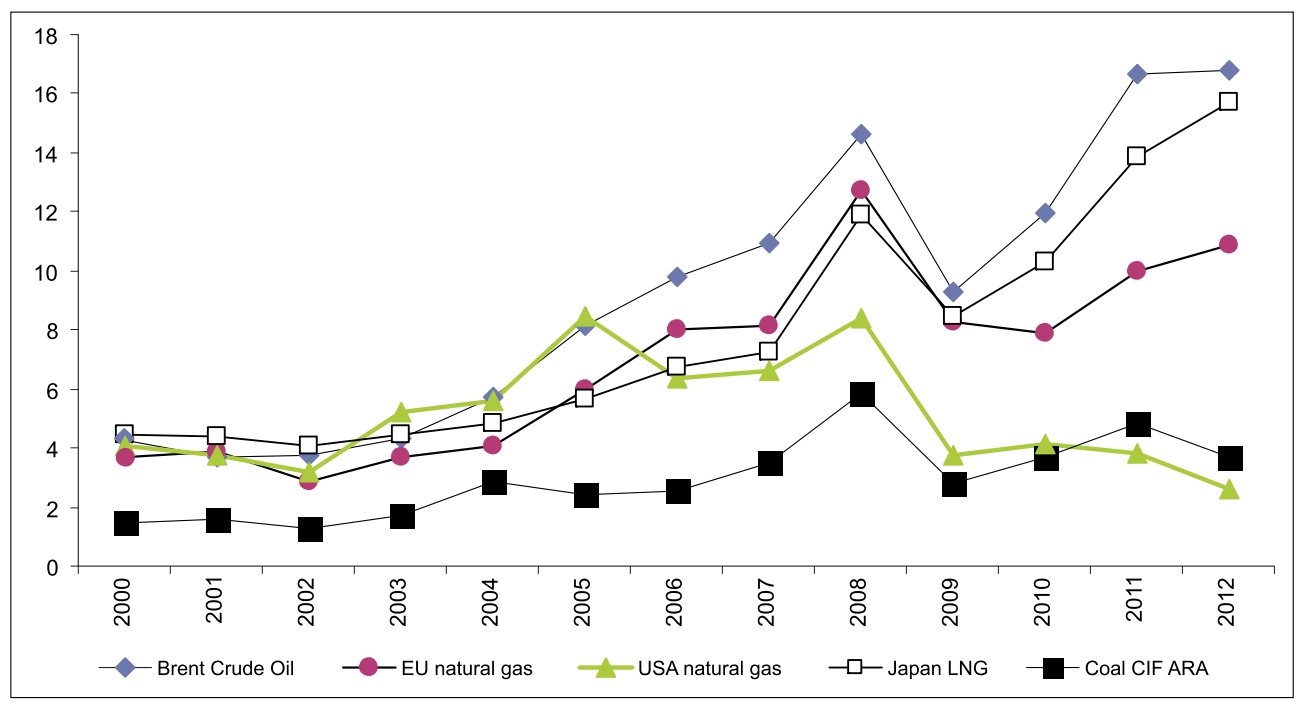

Fig. 6. Fluctuations in natural gas prices in the United States, European Union, and Japanese markets compared to Brent crude oil price fluctuations and CIF ARA coal [USD/GJ]

Source: the authors' own work based on the World Bank's data

Rys. 6. Zmienność cen gazu ziemnego na rynku w USA, UE i Japonii na tle zmian ceny ropy Brent oraz węgla CIF ARA [USD/GJ] 
As a result, all nuclear power plants in the country saw their operations suspended, followed by growth in the use of natural gas in electricity production TWh: 300.4 in 2010; 374.0 in 2011 (IEA 2013). These significant changes in Japan's energy market, the biggest importer of liquefied gas worldwide (LNG), affected the fluctuations in the gas prices (the rise in LNG prices).

Accordingly, when analysing natural gas's position in the European market (which fell slightly in 2012), attention should be paid to both liquefied gas prices (which remained very high) as well as to changes in the coal market. Low prices of solid fuels are to be associated with the 'shale gas revolution' on the American continent, and low gas prices and the broader use of gas in energy generation affect the growth of American coal exports into Europe. In 2011, the net export of US coal amounted to 85 million tonnes, and in 2012 increased to 106 million tonnes, which assured the United States' position as the world's third largest exporter of coal. US coal is also sent to Poland (in m/t) 1.85 in 2010, 1.32 in 2011, and 0.80 in 2012 (Grudziński 2012; Grudziński 2013; IEA 2013; Olkuski 2013).

Figure 7 shows how natural gas prices in the US, European, and Japanese markets evolved from January 2011 to September 2013. Gas prices in the American market were clearly lower compared to gas prices in the European or Japanese markets. When comparing the arithmetic mean of prices for the last twenty months, the European gas price has been three-and-a-half times higher than the American gas prices. It should be noted that the low levels of gas prices seen in the American market in recent years, advantageous to gas users both households (Table 3 ) and industrial customers (Table 2) are a particular problem for gas

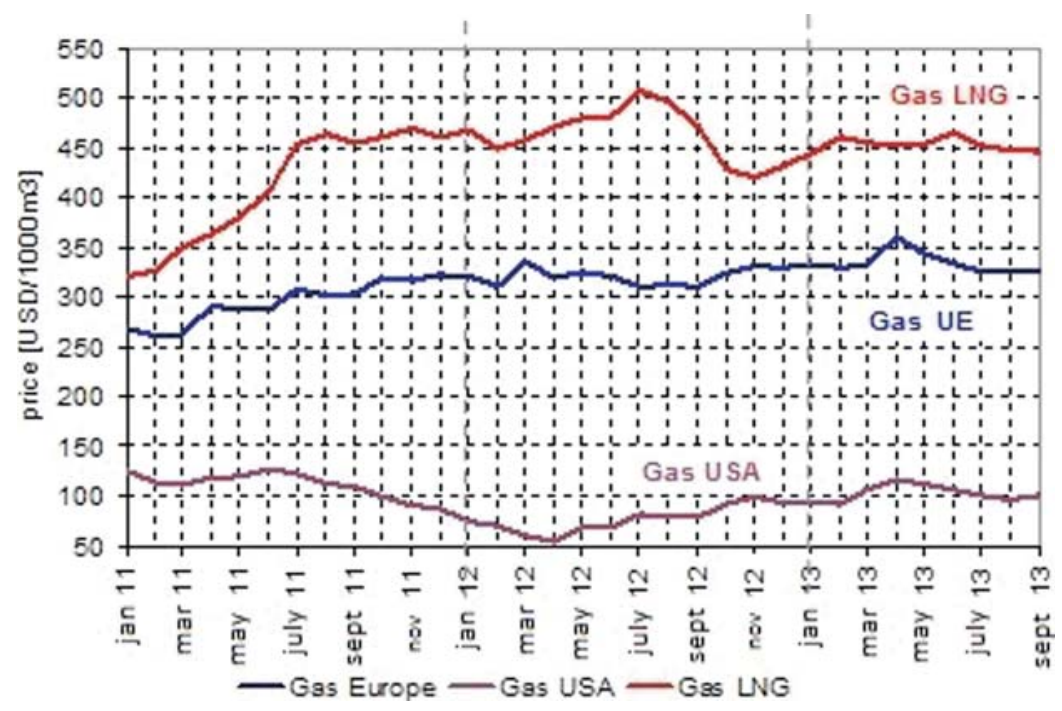

Fig. 7. Gas prices in the European and American markets, and in LNG supplies to Japan [USD/1000 $\mathrm{m}^{3}$ ] Source: the authors' own work based on the data of the World Bank (World Bank ...)

Rys. 7. Porównanie cen gazu na rynku europejskim, amerykańskim oraz w dostawach gazu LNG do Japonii [USD/1000 $\mathrm{m}^{3}$ ] 
Gas prices for industrial customers [USD/toe]

Ceny gazu dla odbiorców przemysłowych [USD/toe]

\begin{tabular}{|l|c|c|c|c|c|c|c|c|c|c|c|c|c||}
\hline \hline \multicolumn{1}{|c|}{ Country } & 2000 & 2001 & 2002 & 2003 & 2004 & 2005 & 2006 & 2007 & 2008 & 2009 & 2010 & 2011 & 2012 \\
\hline \hline Czech Republic & 164.0 & 173.2 & 192.9 & 226.1 & 241.6 & 325.0 & 447.0 & 435.2 & 682.3 & 586.8 & 589.5 & 656.7 & 630.9 \\
\hline France & 186.4 & 207.9 & 191.0 & 254.6 & 291.3 & 366.9 & 458.0 & 460.1 & 674.8 & 487.8 & 538.4 & 665.7 & 660.8 \\
\hline Germany & 208.8 & - & - & - & 370.3 & 442.6 & 582.8 & 640.1 & 739.2 & 617.2 & 601.6 & 702.6 & 659.5 \\
\hline Hungary & 121.8 & 136.8 & 160.0 & 207.7 & 319.7 & 384.0 & 501.3 & 649.1 & 836.7 & 679.4 & 474.9 & 563.8 & 559.4 \\
\hline Italy & - & - & - & - & 333.8 & 390.9 & 504.6 & 545.7 & 718.3 & 619.6 & 536.7 & - & - \\
\hline Poland & 147.8 & 192.5 & 192.3 & 195.5 & 199.4 & 249.6 & 326.9 & 416.7 & 590.8 & 480.8 & 505.3 & 550.1 & 568.1 \\
\hline Slovakia & 112.7 & 118.4 & 147.6 & 245.1 & 270.0 & 319.4 & 421.1 & 467.0 & 691.6 & 574.1 & 594.1 & 648.9 & 678.8 \\
\hline Spain & 194.9 & 195.5 & 183.9 & 226.7 & 239.6 & 282.4 & 394.3 & 422.5 & 540.7 & 482.0 & 433.8 & 487.4 & 568.2 \\
\hline United Kingdom & 116.3 & 156.0 & 162.7 & 183.0 & 225.5 & 332.0 & 426.1 & 370.0 & 495.5 & 392.3 & 365.3 & 458.9 & 496.8 \\
\hline Canada & 99.8 & 120.9 & 139.3 & 233.5 & 248.5 & 323.4 & 302.3 & 240.1 & 391.4 & 191.8 & 177.9 & 199.1 & - \\
\hline United States & 190.0 & 220.7 & 171.6 & 248.6 & 280.1 & 361.3 & 335.6 & 326.4 & 412.6 & 227.3 & 230.4 & 219.0 & 163.8 \\
\hline \hline
\end{tabular}

Source: the authors' own work based on (IEA, 2000-2013b)

companies because they do not cover their costs. The problem is being offset, to a certain extent, by the total production of oil \& natural gas. Oil prices remained at a relatively high level, over $100 \mathrm{USD} / \mathrm{bbl}$.

Following the shifts in natural gas prices, both for industrial customers and households from 2000 to 2012, it is apparent that in the early 21st century gas prices did not differ that much between the countries in Europe and those from the American continent, represented by Canada and the United States. By 2012, however, the difference in gas prices for industrial customers between, for example, France and the US was approximately $400 \%$. In the case of gas prices for households these differences were slightly lower; between Spain and the US they were roughly $330 \%$. When comparing the levels of natural gas prices in Poland with gas prices in other EU countries, particularly with respect to households, it can be noted that in Poland the prices of gaseous fuel were relatively low. But looking at gas prices in purchasing power parities leads to rather significantly different conclusions - from this perspective gas prices in Poland were among the highest (Janusz 2013).

Significant differences between gas prices for industrial customers in the US and EU countries seriously influence the growth of gas's share in the US's energy mix and the stagnation in the gas sector in the European Union. This theory is supported by the fact that between 2008 and 2011, a growth in electricity production was recorded in units based on 


\begin{tabular}{|c|c|c|c|c|c|c|c|c|c|c|c|}
\hline $\begin{array}{l}\mathrm{N} \\
\stackrel{\sim}{\sim}\end{array}$ & $\begin{array}{l}\stackrel{m}{n} \\
\stackrel{m}{=}\end{array}$ & $\begin{array}{l}\stackrel{+}{i} \\
\stackrel{\infty}{0} \\
\stackrel{-}{0}\end{array}$ & $\begin{array}{l}\overrightarrow{0} \\
\stackrel{-}{=}\end{array}$ & $\stackrel{\vec{n}}{\stackrel{2}{R}}$ & 1 & 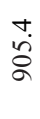 & $\begin{array}{l}\infty \\
\infty \\
\infty \\
\infty \\
\infty\end{array}$ & 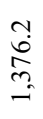 & $\frac{r}{n}$ & I & $\stackrel{\circ}{\stackrel{\odot}{\digamma}}$ \\
\hline $\overrightarrow{\vec{a}}$ & 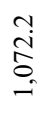 & $\begin{array}{l}\stackrel{\sim}{I} \\
\simeq\end{array}$ & $\stackrel{\widehat{a}}{\Rightarrow}$ & $\stackrel{n}{\tilde{N}}$ & 1 & $\begin{array}{c}\dot{m} \\
\hat{\sigma}\end{array}$ & $\begin{array}{l}n \\
\stackrel{\infty}{2}\end{array}$ & $\begin{array}{l}n \\
\tilde{n} \\
=\end{array}$ & $\begin{array}{l}a \\
\dot{0} \\
\infty\end{array}$ & 㫄 & $\begin{array}{l}n \\
\text { id } \\
+\end{array}$ \\
\hline $\begin{array}{l}0 \\
0 \\
0\end{array}$ & $\begin{array}{l}\hat{n} \\
\infty \\
\infty \\
\infty\end{array}$ & $\begin{array}{l}\text { n} \\
\stackrel{8}{0} \\
0\end{array}$ & $\begin{array}{l}\infty \\
\infty \\
\infty \\
0\end{array}$ & 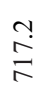 & $\begin{array}{l}\stackrel{n}{n} \\
\ddot{n}\end{array}$ & $\begin{array}{l}\infty \\
\infty \\
\infty \\
\infty\end{array}$ & $\underset{\infty}{\infty}$ & 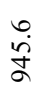 & $\frac{m}{n}$ & $\begin{array}{l}0 \\
\infty \\
\stackrel{0}{f}\end{array}$ & $\stackrel{n}{\stackrel{r}{F}}$ \\
\hline
\end{tabular}

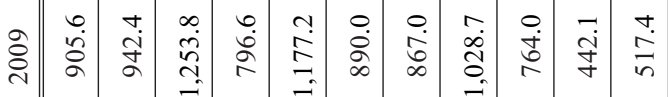

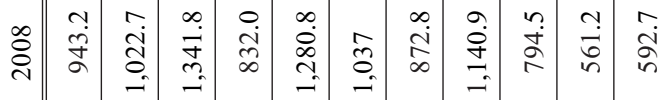


natural gas from 911 to 1,045 TWh. Within the European Union, these changes can be best traced to the case of Great Britain, since the country is the leading producer of electricity from natural gas. In 2012 the share of gas in electricity production amounted to $27.5 \%$, and compared with 2011 gas consumption for this purpose fell by as much as $31.7 \%$. In this period, a strong growth of $31.9 \%$ was recorded in the use of coal for power generation. If comparing data from the first quarter of 2013 and 2012, there is no growth in gas usage in the British energy sector. The decline in demand for gas is due to the high prices of this energy carrier (DECC 2013).

It is worth adding that the US's low natural gas prices also give a stimulus to invest in other economic sectors where the demand for natural gas is significant. Investment activity of European companies in the chemical industry can also be seen overseas, for example, in the activities of SABIC or BASF. Natural gas is a valuable commodity frequently used in the chemical industry. In the manufacture of fertilisers, the purchase costs of natural gas are prevalent factors in cost pricing (Gross-Gołacka et al. 2013).

\section{Impact of global trends on natural gas development in Poland}

The comparison of changes in the EU and Polish natural gas sectors from 2008-2012 shows that while the former is characterised by stagnation - in fact a decrease in natural gas consumption by $53.4 \mathrm{bcm}$ the domestic gas market has experienced an increase in the demand for gas of $13.3 \%$, which is equivalent to $1.86 \mathrm{bcm}$ (the Ministry of Economy, 2013). However, while evaluating natural gas consumption levels per capita during a given year, a significant difference can be seen - the EU market holds a clear advantage over the domestic market in terms of natural gas consumption per capita (Table 4). In recent years, this ifference has decreased slightly, but the country's natural gas consumption per capita is still among the lowest in the EU. Lower gas consumption in Poland is mainly due to the extensive use of solid fuels in the energy sector (the share of gas amounts to some $3 \%$ ), and also to a degree due to difficulties households have in accessing natural gas distribution networks, particularly in the northwestern part of the country (Fig. 8). Conversely, in the case of the US an increase in natural gas consumption per capita can be seen, which is to be associated with successful unconventional gas development.

In recent years, one of the biggest impacts on the domestic natural gas economy has come from shale formations. Poland is a European leader in carrying out exploration work and reporting of unconventional gas resources. LNG technology is also a growing consideration in gas trading, and by the end of next year the Świnoujście LNG terminal is to be put in service. EU membership and application of Community law imposes on the domestic natural gas sector further requirements aimed at liberalisation of the natural gas market.

Since 2009, action has been taken to assess the volume of natural gas in non-conventional deposits; however, due to insufficient information, different methodologies adopted, and calculations based on North American deposit-related data, these calculations vary widely 
Natural gas consumption per capita from 2008-2012 [cubic metres]

Zmiana wskaźnika jednostkowego zużycia gazu ziemnego w latach 2008-2012 [m³]

\begin{tabular}{|r|l|r|r|c||}
\hline \hline No & \multicolumn{1}{|c|}{ Country } & 2008 & 2012 & Change [\%] \\
\hline \hline 1. & Belgium & 1,585 & 1,622 & 2.3 \\
\hline 2. & France & 691 & 691 & -6.3 \\
\hline 3. & Spain & 859 & 667 & -22.3 \\
\hline 4. & Canada & 2,893 & 2,936 & 1.5 \\
\hline 5. & Germany & 986 & 925 & -6.2 \\
\hline 6. & Poland & 388 & 411 & 5.9 \\
\hline 7. & United States & 2,157 & 2,301 & 6.7 \\
\hline 8. & United Kingdom & 1,630 & 1,242 & -23.8 \\
\hline 9. & European Union & 1,013 & 881 & -13.0 \\
\hline \hline
\end{tabular}

Source: the authors' own work based on BP 2013 and CIA World Factbook 2013

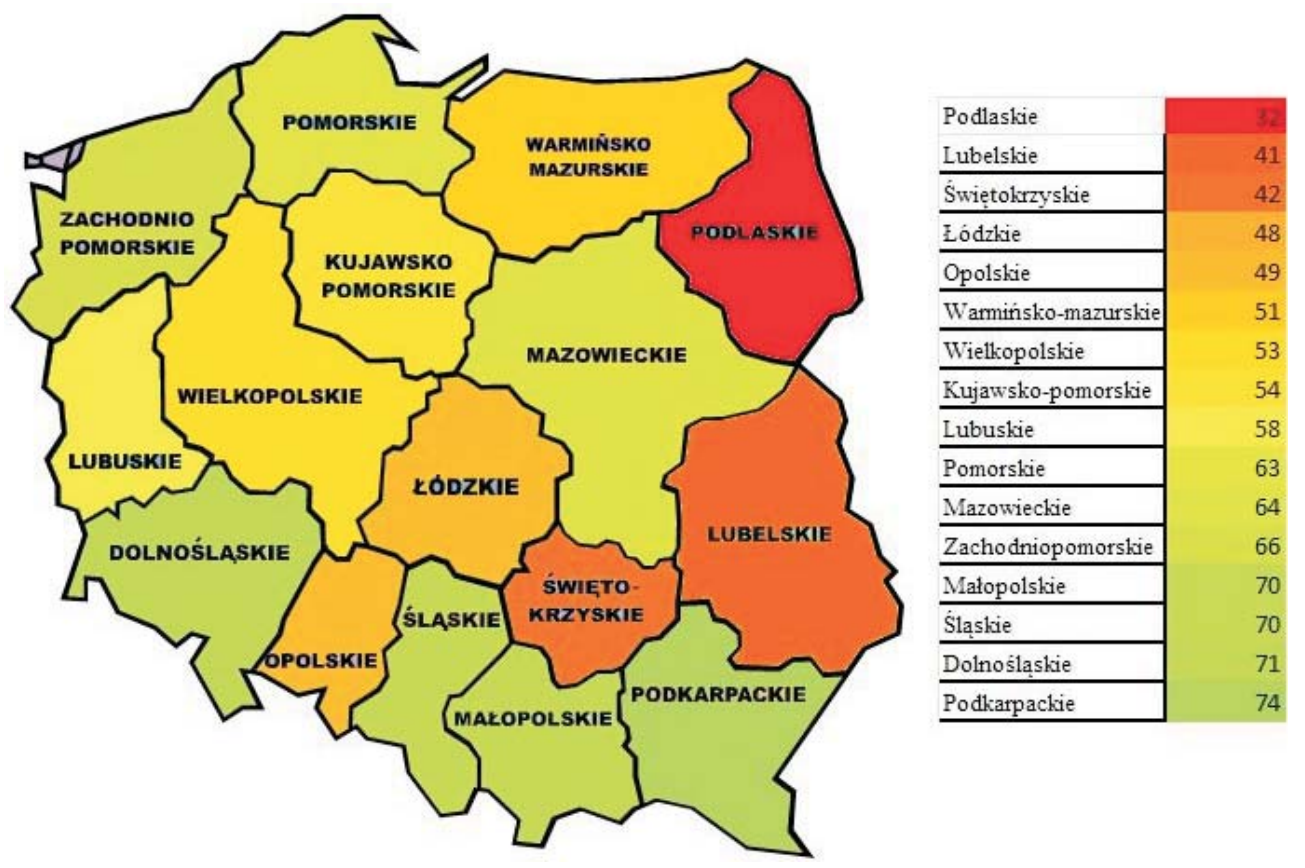

Fig. 8. Access to natural gas distribution networks in households, by provinces [\%] Source: the authors' own work based on GUS (Central Statistical Office), 2012

Rys. 8. Dostępność do sieci gazu ziemnego w gospodarstwach domowych w podziale na województwa [\%] 
(Kaliski et al. 2012b). In Poland, as of October 2013, 51 shale gas exploration wells have been drilled (most of them in the Pomorskie province - 20) and 105 exploration licenses have been granted (as of September 2013). The companies with the highest number of licenses are PGNiG S.A., 16; San Leon Energy Plc, 15; Marathon Oil Company, 11; LOTOS Petrobaltic S.A., 9; and PETROLINVEST S.A, 9 (Ministry of Economy, 2013). Twenty hydraulic fracturing operations have been carried out, including seven slant and horizontal wells. Hydraulic fracturing, or "fracking", is a key element in shale gas drilling technology (Rychlicki, Siemek 2011). Any success in shale gas exploration and its development mainly depends on how strongly individual investors are determined and want to succeed (Borkowski et al. 2012). According to the study Energy Aspects 2013, Poland and the United Kingdom will start industrial-scale extraction of shale gas, with the total EU production in 2020 amounting to 17 bcm (Fig. 9). Canada's Talisman Energy Inc., and the US's Marathon Oil are companies which have ended their shale gas exploration activities in Poland. At present, the existing regulatory environment is being adapted to allow the development of non-conventional hydrocarbon deposits in Poland. EU countries do not have a common approach to shale gas. Whereas the United Kingdom and Poland, for instance, can be considered in favour of this energy carrier, there are also a number of countries against this source of energy the attitude of the French government, for example (Johnson, Boersma 2013). Certainly, the European Parliament decision of 9 October 2013 requiring investors to carry out a comprehensive assessment of the potential environmental impacts of hydraulic fracturing for shale gas exploration is a step away from starting the commercial production of shale gas in EU countries.

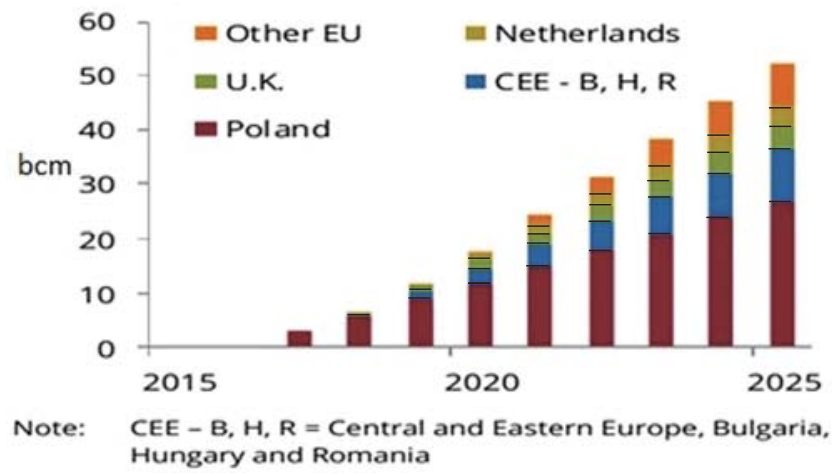

Fig. 9. Shale gas production forecast by 2025 [bcm] Source: (Energy Aspects 2013)

Rys. 9. Prognoza wydobycia gazu z łupków do 2025 r. [mld $\mathrm{m}^{3}$ ]

In light of the increasing contribution of LNG in international natural gas trading, the decision to build a terminal in Świnoujście is to be welcomed. Not only will this investment translate into greater energy security for Poland (and the region) by diversifying natural gas supply routes and sources, but also by ensuring natural gas purchase opportunities even in 
distant markets at a competitive price it could boost the development of the natural gas sector (Siemek et al. 2011). Investing in the development of interconnectors means that the commodity acquired via an LNG terminal can also be directed to neighbouring markets. Regasification capacities $-5 \mathrm{bcm} / \mathrm{y}$ at the first stage, expandable to $7.5 \mathrm{bcm} / \mathrm{y}$ and the fact that it will be the first such plant in the Baltic Sea basin, may boost Poland's role in natural gas trading in the region. The investment will also have positive impacts on the development of a more competitive gas market within Poland (Frączek, Kaliski 2009). The European Union aims to create a single energy market; therefore, a list of infrastructural investments has been established, the purpose of which is to permit the free flow of this commodity. The list included both the possibility to expand the Świnoujście LNG terminal, as well as investments for building interconnectors (Poland-Slovakia; Poland-Lithuania). Such investments encourage the establishment of a common energy market (Mokrzycki et al. 2008).

In Poland, from 1 July 2007, all gas and electricity consumers, including households, are entitled to freely switch suppliers; but in practice these opportunities were not taken advantage of prior to 2010. When it comes to gas sales in the domestic natural gas market, the dominant player on the market has a $94.6 \%$ share in the total gas sales. Such a market structure does not comply with the EU aims that is, creating a competitive natural gas market defined as a diversity of suppliers while ensuring price stability, as well as non-discriminatory and equal access to network infrastructure. In recent years, however, a few changes have occurred in the domestic natural gas market which are to be considered first steps towards a liberalised market, for example (URE 2013):

— in 2011, the share of the dominant player in gas sales fell to $96.4 \%$ from $97.3 \%$ in 2010;

- the number of new consumer gas suppliers increased from 4 at the end of 2011, to 210 at the end of 2012, and to 352 in mid-2013;

- the President of the Energy Regulatory Office increased the number of licenses granted for natural gas foreign trading from 4 in 2011, to 5 in 2012, to 15 in 2013; and for gaseous fuels trading from 4 in 2011, to 21 in 2012, to 35 in 2013.

The liberalisation of the natural gas market, similarly to electricity market, consists of several key elements worth mentioning, such as unbundling, Third Party Access, competition, and supervision by an independent regulator (Kamiński 2009). To speed up the process of liberalisation, amendments are being introduced to the regulations. These have been thoroughly described in the paper by Janusz et al. (2013), and the latest example is the amendment to the Polish Energy Law entered into force on 11 September 2013. This amendment is of fundamental importance for developing the competitive natural gas market in Poland by introducing mandatory public trading. Growth in the use of natural gas trading through the stock exchange should help create a competitive natural gas market. An additional influence on both the liberalisation of the internal natural gas market, as well as the growing consumption of gas, will be the possible development of shale gas (Gawlik 2013). 


\section{Conclusion}

The analysis of natural gas development in North America and in Europe in recent years leads to the following conclusions:

- the 'shale gas revolution' meant not only changes in the natural gas market on the American continent (i.e. an increase in gas supply that translated not only into lower gas prices, but also into growth in the US's GDP), but its effects are increasingly visible on other continents, including in Europe;

- while in America the gas market is visibly developing and in the near future the United States will change its status from a net importer to a net exporter of gas, in the European Union the economic crisis and the growing importance of RES in the energy mix are the main barriers hindering the development of the gas market; in addition, a decline in natural gas recovery from domestic reservoirs and the need to import gas at high prices make it increasingly difficult for gaseous fuels to compete with other energy carriers in the electricity generation sector, and in particular with solid fuels and RES;

- when examining changes in the American and European markets for natural gas, it is necessary to take account of Asian market behaviour which has a great potential for development; the consequences of the accident at the Fukushima nuclear power plant show an example of how European and Asian markets are interrelated and may compete for LNG supplies;

- spot contracts are of growing importance in the international natural gas trade.

Exploration work for unconventional gas, the LNG terminal in Świnoujście, and the liberalisation of the natural gas market are examples of how global (European) trends affect the natural gas market in Poland, one of the very few markets which have been developing in recent years, and where a few significant investments have been completed and had a positive impact on energy security (Janusz 2013). For further development, it is necessary to realise gradual infrastructural investments (LNG terminal, expansion of PMG and interconnectors, as well as the construction of new transmission and distribution networks). At present, the real hope for increased use of gas is associated with the electricity generation sector (Rychlicki, Siemek 2013). In the future, the price of gaseous fuels will be the first factor to determine the level of their use in the energy sector, particularly in relation to coal prices the main energy carrier so far? and also the costs of the purchase of emissions rights or the development of competition in the fuel and energy markets (Grudziński 2011; Kaliski et al. 2012a; Kamiński 2012, 2013). The use of natural gas in power generation offers a number of environmental benefits and makes all generation units highly flexible (Bartela, Skorek-Osikowska 2010; Kotowicz, Bartela 2011).

This paper has been partially funded within the framework of the AGH statutory research No 11.11.210.217 


\section{REFERENCES}

BP: BP Statistical Review of World Energy. June 2002-2013; www.bp.com

The World Bank, 2013 - Global Commodity Markets; www.econ.worldbank.org

ECC 2013 - Department of Energy \& Climate Change 2013 - Energy trends section 5: electricity - Fuel Used in electricity generation and electricity supplied. September 2013; https://www.gov.uk/government/uploads/system/uploads/attachment_data/file/244725/electricity.pdf

Bartela Ł., Skorek-Osikowska A., 2010 - Ecologic effect of supercritical coal-fired unit connection with gas turbine installation. Rynek Energii, 87 (2), pp. 8-13

Borkowski et al. 2012 - B orkowski D., Jasiński A.W., Kaliski M., Sikora A.P., Stefanowicz J., 2012 - Wyzwania regulacyjne związane z możliwością poszukiwania, rozpoznania i wydobycia węglowodorów ze złóż niekonwencjonalnych w Polsce. Rynek Energii, No 4, pp. 71-78 (Regulatory challenges associated with the possibility to prospect, explore and produce unconventional hydrocarbons in Poland).

CIA 2013 - The World Factbook; www.cia.gov/index.html

Energy Aspects, 2013 - Shale elsewhere. Published 24 July 2013 by Trevor Sikorski.

Frączek P., Kaliski M., 2009 - The Deregulation of Natural Gas Markets and its consequences for Gas Recipients in the EU. Archives of Mining Sciences, Vol. 54 (2009), No 4, pp. 739-752.

G a w lik L., 2013 - Gaz ziemny z łupków w Polsce - raport. Polski Komitet Światowej Rady Energetycznej. Wyd. Instytutu GSMiE, Warszawa; www.wec-pksre/publikacje.html (Shale gas in Poland)

Gross-Gołacka et al. 2013 - Gross-Gołacka E., Lubiewa-Wieleżyński W., Szurlej A., Biały R., 2013 - Wyzwania dla producentów nawozów mineralnych w kontekście liberalizacji krajowego rynku gazu ziemnego. Przemysł Chemiczny, 92(8) 2013, pp. 35-41 (Challenges that producers of mineral fertilisers are facing in the context of liberalisation of the natural gas market).

Grudziński Z., 2011 - Wpływ opłat środowiskowych wynikających z parametrów jakościowych węgla na koszty produkcji energii elektrycznej. Mineral Resources Management (Gospodarka Surowcami Mineralnymi) Vol. 27, issue 1, pp. 115-127 (Environmental charges resulting from coal quality parameters affecting the costs of electricity production).

Grudziński Z., 2012 - Metody oceny konkurencyjności krajowego węgla kamiennego do produkcji energii elektrycznej. Studia Rozprawy Monografie No 180. Wyd. IGSMiE PAN, Kraków, p. 271 (Methods for evaluating the competitiveness of domestic coal in electricity production).

Grudziński Z., 2013 - Gospodarka węglem kamiennym energetycznym na międzynarodowych rynkach Atlantyku i Pacyfiku. Mineral Resources Management (Gospodarka Surowcami Mineralnymi) Vol. 29, issue 2, pp. 5-23 (Steam coal in the Atlantic \& Pacific international markets).

Gru d zińs ki Z., 2013 - Koszty środowiskowe wynikające z użytkowania węgla kamiennego w energetyce zawodowej. Rocznik Ochrona Środowiska t. 15, s. 2249-2266 (Environmental Costs Resulting from the Use of Coal in the Power Sector).

GUS 2012 - Rocznik statystyczny województw. Warszawa. (Statistical Yearbook).

International Energy Agency (IEAa) - Natural Gas Information 2000-2013. Paris.

International Energy Agency (IEA) 2012 - World Energy Outlook 2012. Paris.

International Energy Agency (IEA) 2009 - World Energy Outlook 200. Paris.

International Energy Agency (IEA) 2013 - Key World Energy Statistics. Paris.

International Energy Agency (IEAb) 2000-2013 - Energy Price and Taxes 2000-2013.

J a nus z P., 2013 - Aktualna sytuacja na rynku gazu ziemnego - perspektywy rozwoju. Polityka Energetyczna, 2013, Vol. 16, issue 2 (The present natural gas market situation - development perspectives).

J a n u s z P., 2010 - Zasoby gazu ziemnego w Polsce jako czynnik poprawiający bezpieczeństwo energetyczne, na tle wybranych państw UE. Energy Policy Journal (Polityka Energetyczna) Vol. 13, issue 1, pp. 23-41 (Natural gas resources in Poland as a factor increasing the energy security, compared to selected EU countries).

Janusz et al. 2013 - Janusz P., Pikus P., Szurlej A., 2013 - Rynek gazu ziemnego w Polsce - stan obecny i perspektywy rozwoju. Gaz, Woda i Technika Sanitarna No 1, pp. 2-6 (Natural gas market in Poland its present situation and development perspectives). 
Johnson C., Boersma T., 2013 - Energy (in)security in Poland the case of shale gas. Energy Policy 53, pp. 389-399.

Kaliski et al. 2012 - Kaliski M., Krupa M., Sikora A., 2012b - Forecasts and/or scenarios, including quantification of the distance, timing and costs. Arch. Min. Sci. Vol. 57 (2012), pp. 423-439.

Kaliski et al. 2012a-Kaliski M., Szurlej A., Grudziński Z., 2012a - Węgiel i gaz ziemny w produkcji energii elektrycznej Polski i UE. Energy Policy Journal (Polityka Energetyczna) Vol. 15, issue 4, pp. 201-213 (Coal \& natural gas in electricity generation in Poland, and EU).

Kaliski et al. 2013 - Kaliski M., Krupa M., Rychlicki S., Siemek J., Sikora A.P., 2013 - Estymacje kosztów otworów poszukiwawczych i wydobywczych dla złóż ropy i gazu w basenach geologicznych w Polsce. Mineral Resources Management (Gospodarka Surowcami Mineralnymi) Vol. 29, issue 3, pp. 167-178 (Estimation of exploration and production wells' costs for oil \& gas deposits in the geological basins in Poland).

Kamiński J., 2009 - The impact of liberalisation of the electricity market on the hard coal mining sector in Poland. Energy Policy Vol. 37, Issue 3.

Kamiński J., 2012 - The development of market power in the Polish power generation sector: A 10-year perspective. Energy Policy Vol. 42.

K a mińs ki J., 2013 - A blocked takeover in the Polish power sector: A model-based analysis. Energy Policy.

Kotowicz J., Bartela Ł., 2011 - The influence of the legal and economical environment and the profile of activities on the optimal design features of a natural-gas-fired combined heat and power plant. ENERGY Vol. 36, Issue 1, pp. 328-338.

Michałowski et al. 2012 - Michałowski M., Tora B., Čablík V., Černotová L., 2012 - Wybrane problemy wydobycia gazu łupkowego. Rocznik Ochrona Środowiska t. 14, s. 866-874 (Selected Issues of Shale Gas Exploitation).

Ministerstwo Gospodarki, 2013 - Sprawozdanie z wyników monitorowania bezpieczeństwa dostaw paliw gazowych za okres od dnia 1 stycznia 2012 r. do dnia 31 grudnia 2012 r. Warszawa; www.mg.gov.pl (Report on gaseous fuel security supply monitoring results, 1 January, 2012 - 31st December, 2012).

Ministerstwo Środowiska, 2013 - Porozmawiajmy o łupkach: http://lupki.mos.gov.pl/gaz-z-lupkow/informacje-podstawowe

Mokrzycki et al. 2008 - Mokrzycki E., Ney R., Siemek J., 2008 - Światowe zasoby surowców energetycznych. Wnioski dla Polski. Rynek Energii, 2008, No 6, pp. 2-13 (Global resources of energy fuels. Conclusions for Poland).

Olkuski T., 2013 - Zależność Polski w zakresie importu węgla kamiennego. Mineral Resources Management (Gospodarka Surowcami Mineralnymi) Vol. 29, issue 3, pp. 115-130 (Poland's dependency on coal imports).

Rychlicki S., Siemek J., 2011 - Gaz łupkowy - zasoby i technologia. Rynek Energii No 3, pp. 3-8 (Shale gas - resources \& technology).

R y chlicki S., S i e m e k J., 2013 - Stan aktualny i prognozy wykorzystania gazu ziemnego do produkcji energii elektrycznej w Polsce. Mineral Resources Management (Gospodarka Surowcami Mineralnymi) Vol. 29, issue 1, pp. 5-14 (Present situation \& forecasts for the use of natural gas in electricity generation in Poland).

Siemek et al. 2011 - Siemek J., Kaliski M., Rychlicki S., Sikora S., Janusz P., Szurlej A., 2011 Importance of LNG technology in the development of world's natural gas deposits. Mineral Resources Management (Gospodarka Surowcami Mineralnymi) Vol. 27, issue 4, pp. 109-130.

S i e m e k J., N a g y S., 2012 - Energy Carriers Use in the World: Natural Gas - Conventional and Unconventional Gas Resources. Archives of Mining Sciences Vol. 57, No 2, pp. 283-312.

Van der Ho e ve n M., 2012 - World Energy Outlook 2012, Warszawa, 14 October.

Urząd Regulacji Energetyki, 2013 - Sprawozdanie z działalności Prezesa Urzędu Regulacji Energetyki w 2012 r. Warszawa, March (Report on the activities of the President of the Energy Regulatory Office). 


\title{
GOSPODARKA GAZEM ZIEMNYM NA RYNKU AMERYKAŃSKIM I EUROPEJSKIM
}

\author{
Słowa kluczowe
}

Gaz ziemny, niekonwencjonalne złoża gazu, gaz z łupków, LNG, liberalizacja

\section{Streszczenie}

W latach 2001-2012 międzynarodowy obrót gazem ziemnym zwiększył się o 86,4\%, przy czym zauważalny jest stopniowy wzrost znaczenia technologii LNG. W 2005 r. udział przypadający na LNG w całkowitym obrocie stanowił 26\%, a w 2012 r. - 32\%. Światowe zużycie gazu ziemnego w 2012 r. w porównaniu do roku poprzedniego zwiększyło się o około $2 \%$ i osiagnę̧ło 3,3 bln $\mathrm{m}^{3}$. W Ameryce Północnej odnotowano znaczący wzrost zużycia $27,5 \%$, natomiast w przypadku krajów UE zauważalny jest spadek konsumpcji tego paliwa $-2,3 \%$. Autorzy przedstawili zmianę udziału gazu ziemnego w strukturze zużycia energii pierwotnej na rynku europejskim oraz amerykańskim, zauważalne jest umocnienie się roli tego surowca energetycznego w przypadku rynku amerykańskiego (2011 r. - 28,3\%; 2012 r. - 30,0\%) oraz lekki spadek w Europie (2011 r. - 24,2\%; 2012 r. - 23,9\%). Artykuł przedstawia ponadto zmiany jakie nastapiły w obszarze uzależnienia od importu gazu na rynku amerykańskim (spadek importu gazu ziemnego dzięki zagospodarowaniu niekonwencjonalnych złóż gazu) oraz europejskim (spadek pozyskania gazu ze z własnych złóż, wzrost znaczenia importu gazu, w tym LNG). Ponadto przedstawiono zmiany cen gazu ziemnego na rynku europejskim, amerykańskim oraz ceny LNG dostarczanego do Japonii, a także zaprezentowano i skomentowano tendencje zmian cen gazu ziemnego dla odbiorców przemysłowych i gospodarstw domowych w USA, Kanadzie (znaczący wpływ na spadek cen miała „rewolucja lupkowa”) i wybranych państwach UE.

Zaprezentowano i omówiono wpływ zmian na globalnym rynku gazu ziemnego na sektor gazowy w Polsce w ciągu ostatnich lat. Przybliżono także podejmowane działania w zakresie stworzenia konkurencyjnego rynku gazu ziemnego w Polsce.

NATURAL GAS ECONOMY IN THE UNITED STATES AND EUROPEAN MARKETS

Key words

Natural gas, unconventional gas, shale gas, LNG, liberalisation

\section{Abstract}

From 2001-2012, international trade in natural gas increased by $86.4 \%$, with LNG technology visibly growing in importance. In 2005, the share of LNG in the total turnover accounted for $26 \%$, while in 2012 for $32 \%$. In 2012, global natural gas consumption, compared to the previous year, increased by $2 \%$, reaching $3.3 \mathrm{bcm}$. North America recorded a significant increase of $27.5 \%$ in the consumption of gas, whereas in EU countries the consumption of this fuel decreased by $2.3 \%$.

This paper examines how the share of natural gas in primary energy consumption has changed in the European and American markets; the role of this energy source has been strengthening in the US market $(28.3 \%$ in $2011 ; 30.0 \%$ in 2012) while showing a slight decline in Europe (24.2\% in $2011 ; 23.9 \%$ in 2012). The analysis also presents the changes that occurred in terms of dependency on gas imports in the US market, with natural gas imports decreasing due to the development of unconventional gas deposits. In comparison, in the European market lower gas recovery from domestic reserves has meant increased importance of gas imports, including LNG. The paper presents changes in natural gas prices in the European and American markets, along with the prices of LNG delivered to Japan. In addition, it reviews trends in natural gas prices for industrial consumers and households in Canada and the United States (where the 'shale revolution' has significantly affected a drop in prices), as well as in selected EU countries. Finally, the impact in recent years of the global natural gas market on the gas sector in Poland is examined. Highlighted are the actions undertaken to establish a competitive gas market. 